\title{
Evaluation of Pediatric Trauma Patients Requiring Pediatric Intensive Care Follow-up and Identifying the Differences in Refugee Children
}

\author{
Çocuk Yoğun Bakım Takibi Gerektiren Pediatrik Travma Hastalarının \\ Değerlendirilmesi ve Mülteci Çocuklara ait Farklııkların Belirlenmesi
}

\author{
Serhat EMEKSIZ1 ${ }^{1}$ Esra KOCKUZU², Leman AKCAN YILDIZ³ , Ali Kansu TEHCl ${ }^{4}$, Basak ALAN4, \\ Recep KAR ${ }^{5}$, Medine Ezgi OCAL ${ }^{5}$ \\ ${ }^{1}$ Ankara Yıldırım Beyazıt University, Ankara City Hospital, Department of Pediatric Intensive Care Unit, Ankara, Turkey \\ 'University of Health Sciences, Ankara City Hospital, Department of Pediatric Intensive Care Unit, Ankara, Turkey \\ ${ }^{3}$ University of Health Sciences, Ankara City Hospital, Department of Pediatric Emergency, Ankara, Turkey \\ ${ }^{4}$ University of Health Sciences, Ankara City Hospital, Department of Pediatrics, Ankara, Turkey \\ ${ }_{5}$ University of Health Sciences, Ankara City Hospital, Department of Pediatric Surgery, Ankara, Turkey
}

\begin{abstract}
Objective: This study aimed to examine the causes and clinical course of trauma in trauma patients requiring pediatric intensive care unit (PICU) follow-up and evaluate possible differences related to demographic characteristics, trauma mechanism, trauma severity, and prognosis in refugee children.

Material and Methods: The records of 175 patients admitted to our PICU between May 1, 2020 and April 30, 2021 with a preliminary diagnosis of trauma were retrospectively reviewed. The patients were divided into two groups as Turkish citizens and Syrian citizens (refugee children). The obtained data were compared between these two groups.

Results: 119 (68\%) were Turkish citizens and 56 (32\%) were refugees. The median age of the Turkish citizens was 6 (3-12; IQR) years and the median age of the refugee patients was 4 (2-10; IQR) years ( $p=0.092)$. Further, 70 (58.8\%) of the Turkish citizens and $43(76.8 \%)$ of the refugee patients were males ( $p=0.027)$. In-vehicle traffic accidents were observed in $27(22.7 \%)$ of the Turkish citizens and 4 (7.2\%) of the refugee patients, with the difference being statistically significant $(p=0.011)$. The rate of non-vehicle traffic accident in the refugee patients was higher than that in the Turkish citizens $(23.2 \%$ and $10 \%$, respectively) ( $p=0.035)$. Ten patients died due to trauma, of which $7(5.8 \%)$ patients were Turkish citizens and 3 (5.3\%) were refugee patients.

Conclusion: In our study, we found that non-vehicle traffic accidents were more common in refugee patients, but there was no clinical difference between Turkish citizens and refugee patients. We think that more careful evaluation of immigrant problems, projects, and studies focused on the child population, improvement of socioeconomic conditions, and regular participation in the education system can reduce injury rates.
\end{abstract}

Key Words: Pediatric intensive care, Refugee children, Trauma

(1)

EMEKSIZS

KOCKUZUE

AKCAN YILDIZ L

TEHCl AK

ALAN B

KAR R

OCAL ME
$0000-0002-8951-4774$ 0000-0002-5760-349X 0000-0003-2584-6144 0000-0002-9914-3321 : $0000-0002-9914-332$ : $0000-0002-7099-8901$ : 0000-0002-7099-8991 0000-0002-3436-3497
Conflict of Interest / Çıkar Çatışması: On behalf of all authors, the corresponding author states that there is no conflict of interest.

Ethics Committee Approval / Etik Kurul Onayı: This study was conducted in accordance with the Helsinki Declaration Principles. The study was approved by Ankara City Hospital Clinical Research Ethics Committee (with approval number E2-21-633).

Contribution of the Authors / Yazarların katkıSI: EMEKSIZ S: Constructing the hypothesis or idea of research and/or article, Planning methodology to reach the Conclusions, Organizing, supervising the course of progress and taking the responsibility of the research/study, Taking responsibility in patient follow-up, collection of relevant biological materials, data management and reporting, execution of the experiments, Taking responsibility in logica interpretation and conclusion of the results, Taking responsibility in necessary literature review for the study, Taking responsibility in the writing of the who or important parts of the study. Reviewing the artice ( taking the responsibility of the research/study, Taking responsibility in patient follow-up, collection of relevant biological materials, data management and reporting, execution of the experiments, Taking responsibility in logical interpretation and conclusion of the results, Taking responsibility in the writing of the whole or important parts of the study. AKCAN YILDIZ L: Constructing the hypothesis or idea of research and/or article, Planning methodolog/ to reach the Conclusions, Organizing, supervising the course of progress and taking the responsibility of the research/study, Taking responsibility in patient follow-up, collection of relevant biological materials, data management and reporting, execution of the experiments, Taking responsibility in logical interpretation and conclusion of the results, Taking responsibility in the writing of the whole or important parts of the study. TEHCI AK. Taking (n) the writing of the whole or important parts of the study. KAR R: Taking responsibility in patient follow-up, collection of relevant biological materials, data management and reporting, execution of the experiments. OCAL ME: Taking responsibility in necessary literature review for the study.

How to cite / Atıf yazım sekli : Emeksiz S, Kockuzu E, Akcan Yildiz L, Tehci AK, Alan B, Kar R, et al. Evaluation of Pediatric Trauma Patients Requiring Pediatric Intensive Care Follow-up and Identifying the Differences in Refugee Children. Turkish J Pediatr Dis 2021;15:394-399.
Received / Geliş tarihi : 02.07.2021 Accepted / Kabul tarihi : 05.08.2021 Online published Elektronik yayın tarihi

DOI:10.12956/tchd.955627 


\section{Öz}

Amaç: Bu çalıșmanın amacı, pediatrik yoğun bakım takibi gereken travma hastalarında, travma nedenlerini ve klinik seyrini incelemek ve mülteci çocuklar özelinde demografik özellikler, travma oluşum mekanizması, travma şiddeti ve prognoz açısından olası farklılıkları değerlendirmektir.

Gereç ve Yöntemler: 1 Mayıs 2020-30 Nisan 2021 tarihleri arasında çocuk yoğun bakım ünitemize travma ön tanısı ile başvuran 175 hastanın kayıtları geriye dönük olarak incelendi. Hastalar Türk vatandaşları ve Suriye vatandaşları (mülteci hastalar) olarak iki gruba ayrıldı. Elde edilen veriler bu iki grup arasında karşılaştııldı.

Bulgular: Hastaların 119'u (\%68) T.C. vatandaşı ve 56'sı (\%32) mülteci hastaydı. T.C. vatandașı hastaların ortanca yaşı 6 (3-12; IQR) ve

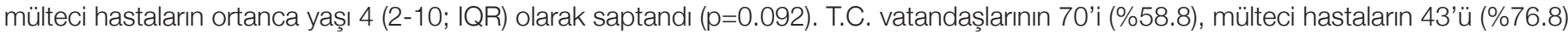
erkekti ( $\mathrm{p}=0.027)$. Araç içi trafik kazası T.C. vatandaşların 27'sinde (\%22.7), mülteci hastaların 4'ünde (\%7.2) görüldü ve farkllık istatistiksel olarak anlamlı bulundu $(\mathrm{p}=0.011)$. Mülteci hastalardaki araç dışı trafik kazası oranı T.C. vatandaşlarına göre daha fazlaydı (\%23.2 ve \%10; sırasıyla) ( $p=0.035)$. Travma nedeni ile 10 hasta hayatını kaybetmişti. Ölen hastaların yedisi (\%5.8) T.C. vatandaşı, üçü (\%5.3) göçmendi.

Sonuç: Çalışmamızda mülteci çocuklarda araç dışı trafik kazasının daha fazla görüldüğünü ancak her iki grupta klinik olarak bir fark olmadığını saptadık. Göçmen sorunlarının daha dikkatli değerlendirilmesi, çocuk nüfusuna odaklı projeler ve çalışmalar, sosyo-ekonomik koşullarının iyileştirilmesi, eğitim sistemine düzenli katılımın sağlanması yaralanma oranlarını azaltabileceğini düşünmekteyiz.

Anahtar Sözcükler: Çocuk yoğun bakım, Mülteci çocuklar, Travma

\section{INTRODUCTION}

Traumas include traffic accidents, falls from a height, drowning, batter, gunshot injuries, sharp object injuries, and injuries from having something fall on. Some of these can cause severe and multiple traumas, require follow-up in pediatric and adult intensive care units, progress with complications involving multiple organ systems, and carry a risk of serious morbidity and mortality (1). The follow-up of pediatric trauma patients is more difficult than the follow-up of adult trauma patients owing to their different anatomical and physiological characteristics and requires more attention. If possible, the follow-up of this patient group should be performed in pediatric intensive care units (PICUs) with a multidisciplinary approach.

Since the unrest in Syria, which began in March 2011, more than 10 million Syrians have been forced to flee their homes and country and have sought refuge in neighboring countries, primarily in Turkey. Undoubtedly, Syrian refugee children are the most vulnerable group affected by the civil war in Syria $(2,3)$. Refugees face many health problems owing to inappropriate living conditions, nutritional problems, living in crowded environments, and inaccessibility to preventive health services. It is noteworthy that the number of foreign national patients, especially Syrian patients, is increasing gradually in Turkey. Turkey has made significant efforts to ensure free and direct access to tertiary health care for Syrian refugee children, many of whom undergo pediatric consultation only when acute symptoms occur. Although health services are free, these children are more likely to be exposed to trauma or accidents caused by being forced to work at a young age due to economic concerns and parental negligence $(4,5)$.

This study aimed to examine the causes and clinical course of trauma in trauma patients requiring PICU follow-up and evaluate possible differences related to demographic characteristics, trauma mechanism, trauma severity, and prognosis in refugee children.

\section{MATERIAL and METHODS}

The study was conducted in Ankara City Hospital Pediatric Intensive Care Unit, which is a tertiary intensive care center with ample experience in the follow-up and treatment of trauma patients. The records of patients admitted to our PICU between May 1, 2020 and April 30, 2021 with a preliminary diagnosis of trauma were retrospectively reviewed. The study was approved by Ankara City Hospital Clinical Research Ethics Committee (with approval number E2-21-633). The study was conducted in accordance with the principles of the Declaration of Helsinki.

\section{Data collection tools}

The patients followed up with a preliminary diagnosis of trauma were evaluated with a study form comprising two parts: the sociodemographic and clinical evaluation section and the mortality and morbidity evaluation section consisting of standard scales prepared by the investigators. The patients were divided into two groups as Turkish citizens and Syrian citizens (refugee children). The obtained data were compared between these two groups.

\section{1) Sociodemographic clinical evaluation form:}

Sociodemographic characteristics such as age, sex, and history were recorded retrospectively from the medical file records of the patients.

The mechanism of the trauma (in-vehicle traffic accident [IVTA], non-vehicle traffic accident [NVTA], fall, bicycle accident, abuse, and hanging), the affected systems and organs (brain, skeleton, thorax, and abdomen), and, if any, the type of cerebral hemorrhage (subarachnoid, subdural, and epidural hemorrhages) were recorded. Examination findings, laboratory results, and radiological data were examined. Data including the clinical course, medications, treatment duration, clinical responses, and, if any, treatment complications were obtained from patient follow-up charts used during the intensive care follow-up of the patients. Whether the patients had undergone surgery, the need for respiratory support therapy such as 
mechanical ventilation, and special supportive treatments including renal replacement therapy and plasma exchange requirements were evaluated. The length to stay in PICU and hospital and the clinical picture at discharge were also recorded.

2) Mortality and Morbidity Evaluation Form: Objective scoring systems such as Pediatric Risk of Mortality III (PRISM III) and Injury Severity Score (ISS), which are evaluated at patient admissions, were used to determine the disease severity, predict recovery from the disease, examine the mortality rate, and evaluate the performance of our intensive care unit.

\section{Statistical analysis}

Descriptive analysis of the results was performed using the Statistical Package for the Social Sciences (SPSS) version 22.0 for Windows (IBM Company, New York, NY). According to the type of distribution, numerical data were expressed as mean \pm standard deviation or median (interquartile range; IQR), and categorical data were expressed as ratios (\%). In cases where categorical variables were present, the differences were evaluated using the chi-squared test. A nonparametric test (Mann-Whitney $U$ test) was used for continuous variables. P-values of $<0.05$ were considered statistically significant.

\section{RESULTS}

A total of 1667 patients were followed up in the PICU during the study period. The number of patients followed up due to trauma was 175 (10.4\%). Of these, 119 (68\%) were Turkish citizens and 56 (32\%) were refugees. The median age of the Turkish citizens was $6(3-12 ; \mathrm{IQR})$ years and the median age of the refugee patients was $4(2-10 ; \mathrm{IQR})$ years $(p=0.092)$. Further, 70 (58.8\%) of the Turkish citizens and 43 (76.8\%) of the refugee patients were males $(p=0.027)$. The demographic and clinical characteristics of the patients are presented in Table I.

The assessment of trauma mechanisms revealed that fallrelated traumas were more common than other traumas in both groups. Fall-related traumas were observed in 69 (57.9\%) of the Turkish citizens and $37(66 \%)$ of the refugee patients ( $\mathrm{p}$ $=0.325)$. IVTAs were observed in 27 (22.7\%) of the Turkish citizens and 4 (7.2\%) of the refugee patients, with the difference being statistically significant $(p=0.011)$. The rate of NVTAs in the refugee patients was higher than that in the Turkish citizens (23.2\% and $10 \%$, respectively) ( $p=0.035$ ). No significant difference was noted in terms of other trauma mechanisms. The characteristics of the trauma mechanisms of the patients are summarized in Table II.

According to the patients' cranial imaging results and clinical conditions, hyperosmolar therapy (using hypertonic saline) was initiated to increase intracranial pressure, if necessary. In total, 116 (66.2\%) patients received hyperosmolar therapy. The need for anticonvulsive therapy (levetiracetam or phenytoin) was determined according to the clinical picture. As the agents selected for treatment were similar in terms of efficacy, medical management was left to the discretion of the attending intensive care physicians. A total of 101 (60\%) trauma patients received anticonvulsive therapy. No significant differences were observed in terms of hyperosmolar therapy and anticonvulsive therapy between the groups. Further, both groups were compared in terms of intubation rates and the total number of intubated days, and no significant differences were noted between the groups (Table I).

As patients without head trauma were followed up in the pediatric surgery intensive care unit, all the patients evaluated in our study had head trauma (hemorrhage and/or fracture). The most common type of hemorrhage in both groups was subdural hemorrhage (35.2\% (Turkish citizens) and 41\% (refugee

Table I: The demographic and clinical characteristics of the patients $(n=175)$.

\begin{tabular}{|c|c|c|c|c|}
\hline Parameter & Total $(n=175)$ & Turkish citizens $(n=119)$ & Refugee patients $(n=56)$ & p \\
\hline Age (years), median (IQR) & $5(3-11)$ & $6(3-12)$ & $4(2-10)$ & 0.092 \\
\hline $\begin{array}{l}\text { Gender } \\
\text { Male, n (\%) } \\
\text { Female, n (\%) }\end{array}$ & $\begin{array}{r}113(64.4) \\
62(35.6)\end{array}$ & $\begin{array}{l}70(58.8) \\
49(41.2)\end{array}$ & $\begin{array}{l}43(76.8) \\
13(23.2)\end{array}$ & $0.027^{*}$ \\
\hline Intubation, $\mathbf{n}(\%)$ & $37(21.1)$ & $24(20.2)$ & $13(23.2)$ & 0.694 \\
\hline Intubation day, median (IQR) & $3(1-9)$ & $3.5(1-11)$ & $2(1-9)$ & 0.578 \\
\hline Surgical, n (\%) & $63(36)$ & $42(35.3)$ & $21(37.5)$ & 0.866 \\
\hline \%3 $\mathrm{NaCl}$ therapy, n (\%) & $116(66.2)$ & $82(68.9)$ & $34(60.7)$ & 0.745 \\
\hline Anticonvulsive therapy, $\mathrm{n}(\%)$ & $105(60)$ & $74(62.1)$ & $31(55.3)$ & 0.238 \\
\hline PICU stay of length, day, median (IQR) & $2(1-4)$ & $2(1-4)$ & $2(1-4.75)$ & 0.475 \\
\hline Hospital stay of length, day, median (IQR) & $7(4-12)$ & $6(3-11)$ & $7(5-12.75)$ & 0.095 \\
\hline ISS, median (IQR) & $9(5-20)$ & $9(2-20)$ & $9(5-14)$ & 0.987 \\
\hline PRISM III, median (IQR) & $6(2-15)$ & $6(2-20)$ & $6(2-14)$ & 0.332 \\
\hline Mortality, n (\%) & $10(5.7)$ & $7(5.8)$ & $3(5.3)$ & 0.999 \\
\hline
\end{tabular}

${ }^{*} p<0.05$, IQR: Interquarter Range, PICU: Pediatric Intensive care Unit, ISS: Injury severity score, PRISM III: Pediatric Risk of Mortality Score 
Table II: The characteristics of the trauma mechanisms of the patients.

\begin{tabular}{|c|c|c|c|c|}
\hline Mechanisms & Total $(n=175)$ & Turkish citizens $(n=119)$ & Refugee patients $(n=56)$ & p \\
\hline IVTA, ${ }^{+}$ & $31(17.8)$ & $27(22.7)$ & $4(7.2)$ & $<0.011^{*}$ \\
\hline NVTA, ${ }^{\dagger}$ & 25 (14.3) & $12(10)$ & $13(23.2)$ & $<0.035^{\star}$ \\
\hline Fall, ${ }^{\dagger}$ & $106(60.6)$ & 69 (57.9) & $37(66)$ & 0.325 \\
\hline Abuse, ${ }^{\dagger}$ & $7(4)$ & $5(4.3)$ & 2 (3.6) & 0.879 \\
\hline Bicycle accident, ${ }^{\dagger}$ & $4(2.2)$ & $4(3.4)$ & 0 & 0.307 \\
\hline Hanging, ${ }^{\dagger}$ & $2(1.1)$ & $2(1.7)$ & 0 & 0.749 \\
\hline
\end{tabular}

${ }^{*} p<0.05, t: n(\%)$, IVTA: In-vehicle traffic accident, NVTA: non-vehicle traffic accident

Table III: Head trauma and additional organ damage data of the patients.

\begin{tabular}{l|c|c|c|c}
\hline \multicolumn{1}{c|}{ Parameter } & Total $(\mathbf{n}=\mathbf{1 7 5})$ & Turkish citizens $(\mathbf{n}=\mathbf{1 1 9})$ & Refugee patients $(\mathbf{n}=\mathbf{5 6})$ & $\mathbf{p}$ \\
\hline SAH & $36(20.5)$ & $27(22.6)$ & $9(16)$ & 0.423 \\
SDH & $65(37.2)$ & $42(35.2)$ & $23(41)$ & 0.504 \\
EPH & $39(22.3)$ & $25(21)$ & $14(25)$ & 0.564 \\
\hline Isolated fracture & $35(20)$ & $25(21)$ & $10(17.8)$ & 0.690 \\
\hline $\begin{array}{l}\text { Additional organ damage } \\
\quad \text { Thorax }\end{array}$ & $34(19.4)$ & $22(18.4)$ & $12(21.4)$ & 0.684 \\
$\quad$ Abdominal organ & $25(14.2)$ & $18(15.1)$ & $7(12.5)$ & 0.818 \\
\hline
\end{tabular}

SAH: Subarachnoid hemorrhage, SDH: Subdural hemorrhage, EPH: Epidural hemorrhage.

patients)) $(p=0.504)$. When concomitant organ damage was evaluated, there were 22 (18.4\%) patients with thoracic damage and 12 patients (21.4\%) with abdominal organ damage among Turkish citizens and 18 patients (15.1\%) with thoracic damage, and 7 patients (12.5\%) with abdominal organ damage among refugee patients, and there were statistical differences between the two groups. Head trauma and additional organ damage data of the patients are presented in Table III.

In our study, $36 \%$ of the patients followed up for trauma underwent surgical intervention; $42(35.3 \%)$ of the Turkish citizens and 21 (37.5\%) of the refugee patients underwent surgery and there was no statistical difference between the two $(p=0.866)$. The median ISS of the Turkish citizens was 9 and that of the refugee patients was 9 , and no significant difference was found between the two $(2-20)(p=0.987)$. The total length of stay in the intensive care unit and hospital stay in both groups were found to be similar. Further, 10 patients died due to trauma, of which 7 (5.8\%) patients were Turkish citizens and $3(5.3 \%)$ were refugee patients. There was no significant difference in the mortality rate between the two groups $(p>$ 0.999) (Table I). When the trauma mechanisms of the deceased patients were evaluated, it was observed that 6 patients died due to IVTA, 2 patients died due to falls, 1 patient died due to NVTA, and 1 patient died due to hanging.

\section{DISCUSSION}

Although there are many studies in the literature evaluating the psychological status and social adaptation problems of refugee children, there is limited data on exposure to trauma, trauma treatment, and follow-up of these children (6-8). In our study, we examined the characteristics of trauma patients followed up in our reference tertiary hospital PICU. Oztan et al. (9) reported the median age as 6 years in a study on pediatric trauma patients (2-11). In another study evaluating Turkish citizens and refugee patients followed up for trauma, the median age was found to be 8 and 9 years, respectively (8). In our study, the age at exposure to trauma was found to be similar to that reported in the literature. Previous studies have shown that boys are more prone to trauma and accidents $(10,11)$. Accordingly, we found that the patients hospitalized in the PICU due to trauma were predominantly males (64.5\%). This can be explained by the tendency of boys to spend more time outside the home, as well as their tendency toward engaging in high-risk behaviors compared to girls, both indoors and outdoors. According to official data, almost half $(45.1 \%)$ of Syrian refugees in Turkey are aged $<18$ years and $53.8 \%$ are males (12). A comparison between Turkish and refugee trauma patients revealed that the number of males exposed to trauma was significantly higher in the refugee patients $(p=0.027)$. In addition to the abovementioned possible reasons, we conclude that this outcome is due to the fact that refugee boys have to start working at an earlier age to support their families and because the male sex ratio is higher among refugee children living in Turkey.

As is well known, poor living and housing conditions can increase the risk of serious traumatic injuries, including those from accidental falls and severe injuries (13). Injuries caused by simple falls in childhood are more common than high-energy injuries such as traffic accidents (14). One of the important 
findings of our study was that the trauma mechanisms to which refugee children were exposed were different from those of Turkish citizens. IVTAs were significantly more common in Turkish citizens, whereas NVTAs were significantly more common in refugee patients. This can be explained by the high probability of families or relatives of Turkish citizen children owning a private vehicle, as well as the increased risk of exposure to the trauma of refugee children owing to housing problems and outdoor work on the streets. Across Turkey, there are an estimated 663.000 refugee children aged 6-17 years who are uneducated and have to live in poor housing conditions (15). The tendency of living together, language limitations, and cultural differences are among the factors that make it challenging for refugee children to adapt to the education system and social life. Many Syrian refugees hesitate to send their children to school due to the perception that their stay in Turkey is temporary (15). Accordingly, we suggest that the longer time spent on the street may be the reason for the higher frequency of NVTAs in refugee children.

Intubation rates vary according to the pediatric trauma score, Glasgow Coma Scale score, the severity of the trauma, general condition of the patient, and the patient profile accepted by the center. In the literature, the need for mechanical ventilation in trauma patients has been reported to range from 1.7\% to $69.3 \%(8,16)$. In our study, $20 \%$ of the trauma patients required mechanical ventilation, and there was no significant difference between the two groups in terms of mechanical ventilation need. In a trauma study conducted in Turkey, it was reported that hospitalization was longer in refugee children (17). However, there was no significant difference in the length to stay in PICU and hospital between the two groups included in our study. It has been shown that mechanical ventilation therapy and high ISS increase the length of stay in the intensive care unit $(10,18)$. Similar ISS scores and duration of mechanical ventilation in our study groups may have caused the duration of stay in the intensive care unit to be similar as well. It has been reported that $20 \%-43.3 \%$ of trauma patients admitted to the PICU underwent surgery $(8,18,19)$. In our study, $36 \%$ of the patients followed up underwent surgery, which corroborates the findings stated in the literature. Further, there was no significant difference between the two groups in terms of undergoing surgery.

In the literature, it has been reported that men have a higher propensity for traumatic injury than women and a higher incidence of death due to traumatic injury $(10,11,20)$. Mortality rates of pediatric trauma patients vary between $0.5 \%$ and $30 \%$ in European countries $(9,10,14,21)$. It has been determined that the most common cause of fatal injuries in children is motor vehicle accidents $(22,23)$. Tucker et al. (24) found that the presence of subarachnoid hemorrhage was associated with increased mortality. Of the 10 patients who died in our study, 6 (60\%) had a subarachnoid hemorrhage, 2 (20\%) had a subdural hemorrhage, 1 had thoracic and abdominal damage, and 1 had hypoxia after hanging. Seven (70\%) of the patients who died were males. The highest mortality rate occurred in male children who developed subarachnoid hemorrhage after IVTAs. It is known that many factors, including socioeconomic status, educational status, and access to health services, affect outcomes such as pediatric trauma-related mortality (25). To reduce childhood accidents and injuries, enlightening warnings should be given to raise full compliance with traffic rules, both in schools and via media, such as social media and television.

\section{Limitations of the Study}

The limitation of our study is that it is a retrospective singlecenter study. As sharp object injuries, other trauma patients without head trauma, and burn patients were followed up by the pediatric surgery department of our hospital, the data of these patients were not included in our study, thereby limiting the number of cases. Further prospective multicenter studies in a large population may help address trauma-related refugee issues.

\section{CONCLUSION}

In our study, we found that NVTAs were more common in refugee patients, but there was no clinical difference between Turkish citizens and refugee patients. We think that more careful evaluation of immigrant problems, projects, and studies focused on the child population, improvement of socioeconomic conditions, and regular participation in the education system can reduce injury rates. Prospective and multicenter studies may aid in gaining more insight into the problems of refugee patients.

\section{REFERENCES}

1. Coulthard MG, Varghese V, Harvey LP, Gillen TC, Kimble RM, Ware RS. A review of children with severe trauma admitted to pediatric intensive care in Queensland, Australia. PLoS One 2019;14:e0211530.

2. Doocy S, Lyles E, Akhu-Zaheya L, Burton A, Weiss W. Health service utilization and access to medicines among Syrian refugee children in Jordan. Int J Health Plann Manage 2016;31:97-112.

3. Guha-Sapir D, Panhuis WG. Conflict-related mortality: An analysis of 37 datasets. Disasters 2004;28:418-28.

4. Aydın D, Şahin N, Akay B. Göç Olayının Çocuk Sağığı Üzerine Etkileri. Behcet Uz Cocuk Hast Derg 2017;7:8-14.

5. Korkmaz AÇ. Sığınmacıların Sağlık ve Hemşirelik Hizmetlerine Yarattığı Sorunlar. Sağlık ve Hemşirelik Yönetimi Dergisi 2014;1:3742.

6. Friedl NK, Muensterer OJ. Special aspects in pediatric surgical inpatient care of refugee children: a comparative cohort study. Children (Basel) 2019; 6:62.

7. Pohl C, Mack I, Schmitz T, Ritz N. The spectrum of care for pediatric refugees and asylum seekers at a tertiary health care facility in Switzerland in 2015. Eur J Pediatr 2017;176:1681-7. 
8. Öztan MO, Bolova G, Sayan A, Özdemir T, Anıl AB, Elmalı F, et al. Çocuk cerrahisi servisinde Travma nedeniyle izlenen Suriyeli hastaların türk hastalarla karşılaştıııması, J Pediatr Emerg Intensive Care Med 2019;6:30-4.

9. Öztan MO, Anıl M, Anıl AB, Yaldız D, Uz İ, Turgut A, et al. First step toward a better trauma management: Initial results of the Northern Izmir Trauma Registry System for children. Ulus Travma Acil Cerrahi Derg 2019; 25:20-8.

10. Hon KL, Huang S, Poon WS, Cheung HM, Ip P, Zee B. Mortality And Morbidity of Severe Traumatic Brain Injuries; A Pediatric Intensive Care Unit Experience Over 15 Years. Bull Emerg Trauma 2019;7:256-62.

11. Zwingmann J, Schmal H, Mehlhorn A, Südkamp NP, Strohm PC. Injury patterns in polytraumatized children and consequences for the emergency room management. Acta Chir Orthop Traumatol Cech 2010;77:365-70.

12. Syria Regional Refugee Response. Inter-Agency Information Sharing Portal. [Last cited on 2021 Jun 02]. Available from: https:// data2.unhcr.org/en/situations/syria/location/113.

13. Hutchings HA, Evans A, Barnes P, Demmler JC, Heaven M, Healy MA, et al. Residential Moving and Preventable Hospitalizations. Pediatrics 2016;138: e20152836.

14. Svantner J, Dolci M, Heim C, Schoettker P. Pediatric trauma: six years of experience in a Swiss trauma center. Pediatr Emerg Care 2019 Dec 13. doi: 10.1097/PEC.0000000000001925. Online ahead of print.

15. Syria's Mental Health Crisis. Brookings Institute. 2016. Available online: https://www.brookings.edu/blog/futuredevelopment/2016/04/25/syrias-mental-health-crisis/ (accessed on 15 August 2019).

16. Ongun EA, Dursun O. Prediction of mortality in pediatric traumatic brain injury: Implementations from a tertiary pediatric intensive care facility Ulus Travma Acil Cerrahi Derg 2018;24:199-206.
17. Bayrak A, Öztürk V, Koluman A, Ziroğlu N, Duramaz A. Injury characteristics and management of orthopaedic trauma in refugee children. Int Orthop 2021;45:649-56.

18. Huang YT, Huang YH, Hsieh CH, Li CJ, Chiu IM. Comparison of Injury Severity Score, Glasgow Coma Scale, and Revised Trauma Score in Predicting the Mortality and Prolonged ICU Stay of Traumatic Young Children: A Cross-Sectional Retrospective Study. Emerg Med Int 2019:5453624.

19. Tambay G, Satar S, Kozacı N, Açıkalın A. Retrospective analysis of pediatric trauma cases admitted to the emergency medicine department. JAEM 2013; 12:812.

20. Ellison P, Cifarelli D, Pearce A, Moore L, Parrish D, Ellison M, Fazi A, et al. Incidence, Prevalence, and Outcomes of Pediatric Trauma in Rural Appalachia (West Virginia) From 2017 to 2019. Cureus 2021;13:e14245.

21. Schoeneberg C, Schilling M, Keitel J, Burggraf M, Hussmann B, Lendemans S. Mortality in severely injured children: experiences of a German level 1 trauma center (2002-2011). BMC Pediatr 2014;14:194.

22. Nance ML, Kallan MJ, Arbogast KB. Factors associated with clinically significant head injury in children involved in motor vehicle crashes. Traffic Inj Prev 2010;11:600-5.

23. Ludvigsson JF, Stiris T, Del Torso S, Mercier JC, Valiulis A, Hadjipanayis A. European Academy of Paediatrics Statement: Vision zero for child deaths in traffic accidents. Eur J Pediatr 2017;176:291-2.

24. Tucker B, Aston J, Dines M, Caraman E, Yacyshyn M, McCarthy $\mathrm{M}$, et al. Early Brain Edema is a Predictor of In-Hospital Mortality in Traumatic Brain Injury. J Emerg Med 2017;53:18-29.

25. Haagsma JA, Graetz N, Bolliger I, Naghavi M, Higashi H, Mullany $\mathrm{EC}$, et al. The global burden of injury: incidence, mortality, disabilityadjusted life years and time trends from the Global Burden of Disease study 2013. Inj Prev 2016;22:3-18. 